\title{
Screening and Histopathological Characterization of Korean Carrot Lines for Resistance to the Root-Knot Nematode Meloidogyne incognita
}

\author{
Yunhee Seo ${ }^{1}$, Jiyeong Park ${ }^{1}$, Yong Su Kim ${ }^{2}$, Yong Park ${ }^{2}$ and Young Ho Kim ${ }^{1 *}$ \\ ${ }^{I}$ Deaprtment of Agricultural Biotechnology and Research Institute for Agriculture and Life Sciences, Seoul National \\ University, Seoul 151-921, Korea \\ ${ }^{2}$ KC Carrot Breeding Institute Co., Ltd., Daegu 706-850, Korea
}

(Received on August 27, 2013; Revised on November 16, 2013; Accepted on November 18, 2013)

In total, 170 carrot lines developed in Korea were screened for resistance to Meloidogyne incognita race 1 to select parental genetic resources useful for the development of nematode-resistant carrot cultivars. Using the gall index (GI), gall formation was examined on carrot roots inoculated with approximately 1,000 second-stage juveniles of the nematode 7 weeks after inoculation. Sixty-one carrot lines were resistant (GI $\leq 1.0$ ), while the other 109 were susceptible (GI > 1.0) with coefficient of variance (CV) of GI for total carrot lines 0.68 , indicating low-variation of GI within the lines examined. The histopathological responses of two carrot plants from resistant and susceptible lines were examined after nematode infection. In susceptible carrots, giant cells formed with no discernible necrosis around the infecting nematodes. In the resistant carrot line, however, no giant cells formed, although modified cells were observed with extensive formation of necrotic layers through their middle lamella and around the infecting nematodes. This suggested that these structural modifications were related to hypersensitive responses governed by the expression of true resistance genes. Therefore, the Korean carrot lines resistant to the nematode infection are potential genetic resources for the development of quality carrot cultivars resistant to $M$. incognita race 1 .

Keywords : breeding, gall formation, giant cell, necrotic layer, true resistance

Carrot (Daucus carota var. sativus) contains vitamins A and $\mathrm{C}$ and fiber, and is one of the top-ten most economically

*Corresponding author.

Phone) +82-2-880-4675, FAX) +82-2-873-2317

E-mail) yhokim@snu.ac.kr important vegetable crops produced; worldwide, it is second only to the potato, comprising a world market value of 100 million dollars with annual trading amounts of 24 million metric tons produced in a total cultivation area of 1.1 million ha (Simon et al., 2008). In 2011, the FAO reported that the world production of carrots and turnips (typically examined together) was almost 35.658 million tons and that almost half was grown in China (FAO, http://faostat. fao.org/site/567/ default.aspx\#ancor). It is also an important root vegetable in Korea with a total cultivation area of 2,849 ha; grown mostly in fields (83.1\%), with some in greenhouses $(16.9 \%)$, totally producing 93,694 tons in 2011. This amount has been increasing continuously during the past 6 years (Ministry for Food, Agriculture, Forestry and Fisheries, Republic of Korea, 2012).

Carrot cultivation aims to produce taproot, which is the most commonly consumed part of a carrot. Carrots are grown under the continuous influence of both biotic and abiotic soil factors. Quantitative and qualitative production of the carrot deteriorates significantly due to soilborne diseases caused by fungi (Fusarium dry rot, crown rot, and Sclerotinia rot), bacteria, actinomycetes (soft rot and scab), and root-knot nematodes (Meloidogyne spp.) (Korean Society of Plant Pathology, 2009). Among them, root-knot nematodes are serious pathogens of paramount importance to carrot cultivation, with symptoms exhibiting galling, forking, stubbing, and fasciculation of the roots that may significantly reduce the commercial value for fresh market consumption (Bridge and Starr, 2007; Johnson and Fassuliotis, 1984; Roberts, 1987; Siroka and Fernandez, 1990).

Four root-knot nematode species have been reported to be distributed globally, including M. hapla, M. incognita, $M$. arenaria, and M. javanica (Bridge and Starr, 2007; Korean Society of Plant Pathology, 2009). M. hapla is the most common Meloidogyne species in open fields and cooltemperate climatic regions, while the others are tropical 
root-knot nematode species found in hot tropical or warm climates (Anwar and McKenry, 2010; Bridge and Starr, 2007). The most prevalent root-knot nematode species in Korea is M. hapla, considering that the major carrotgrowing areas are open fields in Jeju Province during the cool-temperature season (Ministry for Food, Agriculture, Forestry and Fisheries, Republic of Korea, 2012). However, the other three root-knot nematodes may be able to spread throughout carrot fields in the near future with increasing temperatures due to global climate change (Chakraborty et al., 2000; Harris et al., 2006; IPCC, 2007) and/or during greenhouse cultivation at warmer temperatures, in which $M$. incognita and M. arenaria are most common (Kim, 2001; Kim et al., 2001b).

Control of root-knot nematodes typically relies on various methods, including treatment with nematicides, admixtures of soil, rotation, and flooding (Kim et al., 2001a; Kim and Choi, 2001). The use of resistant cultivars for rotation is a highly effective and environmentally friendly method to control root-knot nematodes (Kinlock and Hinson, 1972; Rhoades, 1976). No or little additional cost for controlling root-knot nematodes would be required if reliable cultivars resistant to the nematodes were developed and grown in fields, yielding a proper amount of quality products.

Few studies have been conducted on the breeding of carrot lines resistant to root-knot nematodes in Korea. However, the development of breeding methods using male sterility and evaluation techniques to breed carrot lines with high phenotypic stability, spineless seeds, and highquality root yield have been performed (Choi et al., 1974; Park, 1995a, 1995b; Park and Pyo, 1977, 1988a, 1988b, 1989; Park et al., 2002; Pyo et al., 2001, 2002). Therefore, this study aimed to screen genetic resources of carrot lines developed in Korea for resistance to the rootknot nematode ( $M$. incognita) that can be used to breed nematode-resistant Korean carrot lines and reduce damage caused by the nematode.

\section{Materials and Methods}

Carrot lines and nematode. In total, 170 carrot lines have been developed at the KC Carrot Breeding Institute through a more than 30-year history of study in Korea (Park, 1995a, 1995b; Park and Pyo, 1977, 1988a, 1988b, 1989; Park et al., 2002). They were used for screening assays in our experiments. Seeds of the carrot lines were germinated in vermiculite at $20^{\circ} \mathrm{C}$ for 1 week and then planted in $9 \mathrm{~cm}$ (diameter) $\times 8 \mathrm{~cm}$ (depth) plastic pots filled with sand and potting soil mixture sterilized at $121^{\circ} \mathrm{C}$ for $15 \mathrm{~min}$. The plants grew at $20-25^{\circ} \mathrm{C}$ with watering three times a week for 7 weeks in a greenhouse prior to nematode inoculation. Egg masses of the root-knot nematode ( $M$. incognita race 1) were hand-picked using forceps from the pure cultures maintained on chili pepper plants (Capsicum annuum cv. Bugang) under greenhouse conditions. These were incubated on Baermann funnels for 3-5 days for eggs to hatch into second-stage juveniles (J2) of the nematode (Son et al., 2008; Southey, 1986). Nematodes collected from the funnels were diluted in sterile distilled water (SDW) to obtain a nematode solution with a concentration of about $100 \mathrm{~J} 2 / \mathrm{ml}$. The nematode solution $(10 \mathrm{ml})$ was used for nematode inoculation of each carrot seedling.

Screening of carrot lines for M. incognita. Seven-weekold carrot seedlings at the fourth to sixth true leaf stages planted in plastic pots were inoculated with about 1,000 $\mathrm{J} 2$ of $M$. incognita dispensed in $10 \mathrm{ml} \mathrm{SDW}$, which was poured on the seedling rhizosphere with five replications for each carrot line. Treatment with equivalent amounts of SDW was used as a control. Pots with the carrot seedlings inoculated with nematodes were arranged in randomized complete block design in greenhouse benches and grown at $20 \pm 5^{\circ} \mathrm{C}$. Seven weeks after nematode inoculation, plants were carefully uprooted from pots, and the root systems were gently washed with water to remove adhering soil. The roots were examined visually for root gall formation on each root system. The formation of root galls per root system was examined and the gall index (GI) was assigned as $0=0-10 \%, 1=11-20 \%, 2=21-50 \%, 3=51-80 \%, 4=$ $81-90 \%$, and $5=91-100 \%$ of roots galled (Baker, 1985), which were expressed as averages \pm standard deviations of five replications. Coefficients of variation (CVs) were calculated as the values of standard deviations divided by the corresponding means of the GI and averaged to examine the variance in the GI of all carrot lines tested, indicating $\mathrm{CV}<1.0$ considered to be low-variance, but $\mathrm{CV}>1.0$ high- variance (http://www.readyratios.com/ reference/analysis/coefficient_of_variation.html) The reactions of carrot lines to the nematode infection (resistant ratings) were determined using the root GI and regarded as highly resistant (HR) when $\mathrm{GI} \leq 0.1$, resistant $(\mathrm{R})$ when $\mathrm{GI} \leq 1.0$, and susceptible (S) when GI $>1.0$, which was modified from Sasser et al. (1984).

Structural changes of carrot root tissues infected with M. incognita. Two carrot plants with a GI of 5 and 1, each from a susceptible [L 1205(4), GI = 1.6] or resistant line [L 1213(1), GI = 1.0], were selected to examine their histopathological responses to nematode infection. They were planted and inoculated with $\mathrm{J} 2$, as described above. 
Plants were uprooted from pots 7 weeks after inoculation. Infected carrot root segments (containing galls) were fixed with Karnovsky's fixative consisting of $2 \%$ $(\mathrm{v} / \mathrm{v})$ glutaraldehyde and $2 \%(\mathrm{v} / \mathrm{v})$ paraformaldehyde in $0.05 \mathrm{M}$ cacodylate buffer $(\mathrm{pH}$ 7.2) for $4 \mathrm{~h}$. The root segments were washed in $0.05 \mathrm{M}$ cacodylate buffer $(\mathrm{pH} 7.2)$ three times each for $15 \mathrm{~min}$ and post-fixed in $1 \%$ osmium tetroxide in the same buffer for $2 \mathrm{~h}$ (kept at $4^{\circ} \mathrm{C}$ in a refrigerator). They were washed briefly with distilled water for 1-2 min, and en block stained in $0.5 \%$ uranyl acetate overnight at $4^{\circ} \mathrm{C}$ in a refrigerator. The specimens were then dehydrated in an ethanol series of $30 \%, 50 \%$, $80 \%$, and $90 \%$, and finally three times in $100 \%$ ethanol for $10 \mathrm{~min}$ each. The specimens were further treated with two changes of $100 \%$ propylene oxide each for $15 \mathrm{~min}$ and embedded in Spurr's epoxy resin (Spurr, 1969), followed by polymerization at $70^{\circ} \mathrm{C}$ for $8 \mathrm{~h}$ to embed the specimens. The embedded specimens were sectioned $600 \mathrm{~nm}$ in thicknesses with a glass knife on a MT-X ultramicrotome (RMC, Tucson, AZ, USA). The sections were then stained with $1 \%$ toluidine blue $\mathrm{O}$ in $2 \%$ sodium tetraborate and observed under a compound light microscope (Axiophot; Carl Zeiss, Oberkochen, Germany).

\section{Results}

Screening of carrot lines for $M$. incognita. Formation of root-knot galls on carrots infected with $M$. incognita varied in the GI from 0 (with $0-10 \%$ gall formation) to 5 (with 91-100\% gall formation) 7 weeks after inoculation (Fig. 1). Of the 170 carrot lines screened for root-knot nematode, which showed an average GI from 0.2 to 4.2 with a CV of less than 1 (0.68), 61 were resistant with $\mathrm{GI} \leq 1.0$, while the other 109 were susceptible with a GI >1.0 (Table 1).

Structural changes of carrot root tissues infected with $M$. incognita. Root-knot nematodes were always found in carrot root tissues with galls formed on both susceptible and resistant carrots 7 weeks after inoculation. Characteristics of the structural modifications differed between the susceptible and resistant carrots (Figs. 2 and 3). Light micrographs of susceptible root tissues infected with $M$. incognita 7 weeks after inoculation showed the formation of well-developed giant cells surrounding the nematodes, which were characterized by enlarged cells formed around xylem and phloem in the stele (Fig. 2AD). Feeding tubes and cell wall ingrowths formed in the cytoplasm and adjacent to xylem vessels, respectively, but no necrosis was observed around the infecting nematodes and giant cells (Fig. 2C, D). However, light micrographs of root tissues resistant to the root-knot nematode did not show giant cells, but instead relatively small modified cells around the infecting nematode (Fig. 3A-D). Necrotic layers were observed through the middle lamella of the modified cells and around the nematodes, demarcating the modified cells from each other and from the infecting nematodes (Fig. 3A-D). No feeding tubes or cell wall ingrowths were found in the modified cells of the resistant carrot line infected with $M$. incognita, suggesting that nematodes were not active and giant cell function had decreased. This may have resulted in the retardation of nematode growth and development, which was indicated by the small degenerative-looking nematode bodies (Fig. $3 \mathrm{~A}, \mathrm{D})$ compared to large and intact nematode bodies in the susceptible root tissues (Fig. 2A, B, D)

\section{Discussion}

Of the 170 Korean carrot lines examined for resistance and susceptibility to the root-knot nematode (M. incognita race 1), 61 appeared resistant to nematode infection, showing no or few gall formations with a $\mathrm{GI} \leq 1.0$ and $\mathrm{CV}$ of approximately 0.68 , indicating a low-variance of GI within the lines examined (http://www.readyratios.com/reference/

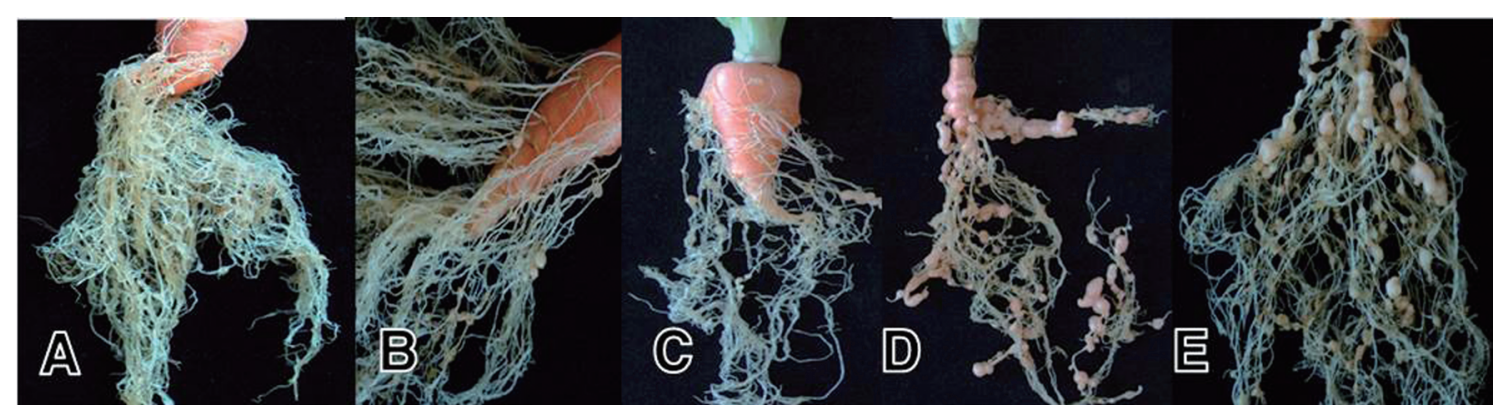

Fig. 1. Gall formation in Korean carrots at 7 weeks after inoculation with approximately 1,000 second-stage juveniles (J2) of Meloidogyne incognita race 1, showing no (A), low (B, C), and severe (D, E) gall formations. 
Table 1. Resistance ratings (RR) of Korean carrot lines determined by the degree of root gall formation [expressed by gall index (GI)] at 7 weeks after Meloidogyne incognita race 1 inoculation

\begin{tabular}{|c|c|c|c|c|c|c|c|c|c|c|c|}
\hline Line no. & $\mathrm{GI}^{\mathrm{a}}$ & $\mathrm{RR}^{\mathrm{b}}$ & Line no. & GI & RR & Line no. & GI & RR & Line no. & GI & RR \\
\hline 207 & $1.75 \pm 0.50^{c}$ & $\mathrm{~S}$ & 423 & $3.00 \pm 0.82$ & $\mathrm{~S}$ & 643 & $2.00 \pm 1.00$ & $\mathrm{~S}$ & 1211(1) & $0.80 \pm 0.8$ & $\mathrm{R}$ \\
\hline 210 & $1.60 \pm 0.55$ & $\mathrm{~S}$ & 424 & $3.50 \pm 0.58$ & $\mathrm{~S}$ & 644 & $3.00 \pm 0.00$ & $\mathrm{~S}$ & 1211(2) & $1.40 \pm 1.1$ & $\mathrm{~S}$ \\
\hline 211 & $1.50 \pm 0.71$ & $\mathrm{~S}$ & 425 & $2.80 \pm 0.84$ & $\mathrm{~S}$ & 645 & $2.40 \pm 1.14$ & $\mathrm{~S}$ & 1211(3) & $0.40 \pm 0.5$ & $\mathrm{R}$ \\
\hline 221 & $3.40 \pm 0.55$ & $\mathrm{~S}$ & 426 & $1.33 \pm 0.58$ & $\mathrm{~S}$ & 646 & $1.50 \pm 0.58$ & $\mathrm{~S}$ & $1211(5)$ & $0.20 \pm 0.4$ & $\mathrm{R}$ \\
\hline 222 & $1.80 \pm 0.45$ & $\mathrm{~S}$ & 427 & $1.75 \pm 0.96$ & $\mathrm{~S}$ & 647 & $1.00 \pm 0.00$ & $\mathrm{R}$ & $1212(1)$ & $1.20 \pm 1.1$ & $\mathrm{~S}$ \\
\hline 223 & $2.60 \pm 0.89$ & S & 428 & $1.67 \pm 0.58$ & S & 648 & $1.80 \pm 0.84$ & $\mathrm{~S}$ & 1213(1) & $1.00 \pm 0.7$ & $\mathrm{R}$ \\
\hline 224 & $2.67 \pm 0.58$ & $\mathrm{~S}$ & 429 & $2.50 \pm 0.71$ & $\mathrm{~S}$ & 649 & $2.60 \pm 0.55$ & S & $1213(3)$ & $1.20 \pm 0.4$ & $\mathrm{~S}$ \\
\hline 225 & $2.00 \pm 0.82$ & $\mathrm{~S}$ & 430 & $1.60 \pm 0.55$ & $\mathrm{~S}$ & 650 & $3.20 \pm 0.45$ & $\mathrm{~S}$ & $1214(1)$ & $0.80 \pm 0.8$ & $\mathrm{R}$ \\
\hline 226 & $2.80 \pm 0.45$ & $\mathrm{~S}$ & 431 & $2.50 \pm 0.58$ & $\mathrm{~S}$ & 651 & $2.50 \pm 0.71$ & $\mathrm{~S}$ & $1214(2)$ & $0.20 \pm 0.4$ & $\mathrm{R}$ \\
\hline 227 & $2.50 \pm 1.00$ & $\mathrm{~S}$ & 434 & $1.00 \pm 0.82$ & $\mathrm{R}$ & 652 & $1.00 \pm 0.00$ & $\mathrm{R}$ & $1214(4)$ & $0.80 \pm 0.4$ & $\mathrm{R}$ \\
\hline 228 & $4.20 \pm 0.45$ & S & 436 & $1.00 \pm 0.00$ & $\mathrm{R}$ & 701 & $2.60 \pm 0.55$ & $\mathrm{~S}$ & $1215(1)$ & $0.20 \pm 0.4$ & $\mathrm{R}$ \\
\hline 252 & $1.60 \pm 0.55$ & $\mathrm{~S}$ & 441 & $0.40 \pm 0.50$ & $\mathrm{R}$ & 702 & $3.00 \pm 0.00$ & $\mathrm{~S}$ & $1215(3)$ & $0.20 \pm 0.4$ & $\mathrm{R}$ \\
\hline 254 & $3.00 \pm 0.82$ & $\mathrm{~S}$ & 442 & $1.00 \pm 1.00$ & $\mathrm{R}$ & 709 & $2.60 \pm 0.89$ & $\mathrm{~S}$ & $1215(4)$ & $0.20 \pm 0.4$ & $\mathrm{R}$ \\
\hline 256 & $1.67 \pm 0.58$ & $\mathrm{~S}$ & 444 & $0.40 \pm 0.50$ & $\mathrm{R}$ & 712 & $2.00 \pm 0.00$ & $\mathrm{~S}$ & $211(2)$ & $1.30 \pm 2.5$ & $\mathrm{~S}$ \\
\hline 260 & $2.00 \pm 1.00$ & $\mathrm{~S}$ & 446 & $0.20 \pm 0.40$ & $\mathrm{R}$ & 714 & $2.67 \pm 0.58$ & $\mathrm{~S}$ & $223(1)$ & $0.20 \pm 0.4$ & $\mathrm{R}$ \\
\hline 263 & $1.50 \pm 0.58$ & $\mathrm{~S}$ & 448 & $0.40 \pm 0.50$ & $\mathrm{R}$ & 718 & $1.80 \pm 0.84$ & $\mathrm{~S}$ & $223(4)$ & $0.20 \pm 0.4$ & $\mathrm{R}$ \\
\hline 266 & $3.60 \pm 0.55$ & $\mathrm{~S}$ & 450 & $0.40 \pm 0.50$ & $\mathrm{R}$ & 719 & $1.25 \pm 0.50$ & $\mathrm{~S}$ & $224(1)$ & $0.50 \pm 0.6$ & $\mathrm{~S}$ \\
\hline 273 & $1.00 \pm 0.00$ & $\mathrm{R}$ & 453 & $0.20 \pm 0.40$ & $\mathrm{R}$ & 720 & $2.75 \pm 0.50$ & $\mathrm{~S}$ & $224(2)$ & $0.40 \pm 0.9$ & $\mathrm{R}$ \\
\hline 274 & $1.67 \pm 0.58$ & $\mathrm{~S}$ & 454 & $0.40 \pm 0.50$ & $\mathrm{R}$ & 721 & $3.25 \pm 0.96$ & $\mathrm{~S}$ & $224(4)$ & $0.20 \pm 0.4$ & $\mathrm{R}$ \\
\hline 278 & $1.40 \pm 0.55$ & $\mathrm{~S}$ & 456 & $0.20 \pm 0.40$ & $\mathrm{R}$ & 723 & $2.75 \pm 1.50$ & $\mathrm{~S}$ & $228(1)$ & $1.00 \pm 1.0$ & $\mathrm{R}$ \\
\hline 280 & $1.00 \pm 0.00$ & $\mathrm{R}$ & 502 & $2.00 \pm 1.00$ & $\mathrm{~S}$ & 724 & $0.75 \pm 0.50$ & $\mathrm{R}$ & $248(5)$ & $0.20 \pm 0.4$ & $\mathrm{R}$ \\
\hline 281 & $1.50 \pm 0.71$ & S & 503 & $1.60 \pm 0.55$ & $\mathrm{~S}$ & 751 & $1.80 \pm 0.84$ & $\mathrm{~S}$ & $249(1)$ & $0.60 \pm 0.9$ & $\mathrm{R}$ \\
\hline 401 & $1.20 \pm 0.84$ & $\mathrm{~S}$ & 504 & $0.67 \pm 0.58$ & $\mathrm{R}$ & 776 & $1.33 \pm 0.58$ & $\mathrm{~S}$ & $249(3)$ & $0.20 \pm 0.4$ & $\mathrm{R}$ \\
\hline 402 & $0.50 \pm 0.71$ & $\mathrm{R}$ & 505 & $1.50 \pm 0.58$ & $\mathrm{~S}$ & 1201(4) & $0.40 \pm 0.50$ & $\mathrm{R}$ & $250(5)$ & $0.40 \pm 0.5$ & $\mathrm{R}$ \\
\hline 403 & $1.00 \pm 0.82$ & $\mathrm{R}$ & 509 & $1.50 \pm 0.58$ & $\mathrm{~S}$ & $1201(5)$ & $0.20 \pm 0.40$ & $\mathrm{R}$ & $251(1)$ & $1.00 \pm 0.8$ & $\mathrm{R}$ \\
\hline 405 & $1.60 \pm 0.55$ & $\mathrm{~S}$ & 510 & $2.40 \pm 0.55$ & $\mathrm{~S}$ & $1202(0)$ & $1.00 \pm 1.00$ & $\mathrm{R}$ & $251(5)$ & $0.80 \pm 0.8$ & $\mathrm{R}$ \\
\hline 406 & $1.60 \pm 1.52$ & $\mathrm{~S}$ & 515 & $2.00 \pm 0.00$ & $\mathrm{~S}$ & $1203(1)$ & $1.80 \pm 0.40$ & $\mathrm{~S}$ & $252(0)$ & $0.60 \pm 0.5$ & $\mathrm{R}$ \\
\hline 407 & $1.50 \pm 0.58$ & S & 519 & $1.40 \pm 0.55$ & $\mathrm{~S}$ & 1203(3) & $1.20 \pm 1.10$ & $\mathrm{~S}$ & $253(3)$ & $1.00 \pm 0.8$ & $\mathrm{R}$ \\
\hline 408 & $2.00 \pm 0.89$ & S & 601 & $3.00 \pm 0.00$ & $\mathrm{~S}$ & 1203(4) & $1.60 \pm 1.10$ & $\mathrm{~S}$ & $254(4)$ & $0.60 \pm 0.5$ & $\mathrm{R}$ \\
\hline 409 & $1.75 \pm 0.50$ & $\mathrm{~S}$ & 603 & $1.25 \pm 0.50$ & $\mathrm{~S}$ & $1204(1)$ & $1.50 \pm 1.00$ & $\mathrm{~S}$ & $256(1)$ & $1.00 \pm 0.8$ & $\mathrm{R}$ \\
\hline 410 & $2.00 \pm 0.82$ & $\mathrm{~S}$ & 607 & $0.60 \pm 0.55$ & $\mathrm{R}$ & $1204(2)$ & $1.40 \pm 0.90$ & $\mathrm{~S}$ & $264(1)$ & $1.00 \pm 1.0$ & $\mathrm{R}$ \\
\hline 411 & $1.00 \pm 0.00$ & $\mathrm{R}$ & 608 & $1.00 \pm 0.00$ & $\mathrm{R}$ & 1204(3) & $2.60 \pm 0.50$ & $\mathrm{~S}$ & $265(2)$ & $0.50 \pm 0.6$ & $\mathrm{R}$ \\
\hline 412 & $1.00 \pm 0.00$ & $\mathrm{R}$ & 610 & $2.00 \pm 1.58$ & $\mathrm{~S}$ & $1204(4)$ & $1.80 \pm 1.10$ & $\mathrm{~S}$ & $266(1)$ & $2.00 \pm 0.0$ & $\mathrm{~S}$ \\
\hline 413 & $1.67 \pm 0.58$ & S & 612 & $3.67 \pm 0.58$ & $\mathrm{~S}$ & $1205(1)$ & $1.30 \pm 1.00$ & $\mathrm{~S}$ & $267(1)$ & $1.20 \pm 0.8$ & $\mathrm{~S}$ \\
\hline 414 & $1.60 \pm 1.14$ & $\mathrm{~S}$ & 617 & $1.25 \pm 0.50$ & $\mathrm{~S}$ & $1205(2)$ & $1.80 \pm 0.40$ & $\mathrm{~S}$ & $267(2)$ & $0.80 \pm 0.8$ & $\mathrm{R}$ \\
\hline 415 & $3.33 \pm 0.58$ & $\mathrm{~S}$ & 622 & $3.00 \pm 0.82$ & $\mathrm{~S}$ & $1205(4)$ & $1.60 \pm 1.90$ & $\mathrm{~S}$ & $268(1)$ & $1.00 \pm 0.8$ & $\mathrm{R}$ \\
\hline 416 & $3.20 \pm 0.84$ & $\mathrm{~S}$ & 623 & $1.67 \pm 1.15$ & $\mathrm{~S}$ & $1206(1)$ & $2.00 \pm 0.70$ & $\mathrm{~S}$ & $269(2)$ & $1.20 \pm 0.8$ & $\mathrm{~S}$ \\
\hline 417 & $1.25 \pm 0.50$ & $\mathrm{~S}$ & 624 & $2.25 \pm 0.96$ & $\mathrm{~S}$ & $1206(2)$ & $1.30 \pm 0.50$ & $\mathrm{~S}$ & $402(1)$ & $0.40 \pm 0.9$ & $\mathrm{R}$ \\
\hline 418 & $1.50 \pm 0.58$ & $\mathrm{~S}$ & 628 & $1.33 \pm 0.58$ & $\mathrm{~S}$ & $1207(3)$ & $0.80 \pm 1.10$ & $\mathrm{R}$ & $410(2)$ & $0.40 \pm 0.5$ & $\mathrm{R}$ \\
\hline 419 & $1.25 \pm 0.50$ & $\mathrm{~S}$ & 631 & $1.80 \pm 0.45$ & $\mathrm{~S}$ & $1209(5)$ & $1.40 \pm 1.10$ & $\mathrm{~S}$ & $422(1)$ & $1.40 \pm 0.5$ & $\mathrm{~S}$ \\
\hline 420 & $1.50 \pm 0.58$ & $\mathrm{~S}$ & 631 & $1.50 \pm 0.58$ & $\mathrm{~S}$ & $1210(2)$ & $1.60 \pm 0.50$ & $\mathrm{~S}$ & $422(2)$ & $0.40 \pm 0.5$ & $\mathrm{R}$ \\
\hline 421 & $0.4 \pm 0.50$ & $\mathrm{R}$ & 632 & $2.25 \pm 0.96$ & $\mathrm{~S}$ & $1210(4)$ & $0.80 \pm 0.80$ & $\mathrm{R}$ & \multirow[t]{2}{*}{$\mathrm{CV}^{\mathrm{d}}$} & \multirow{2}{*}{\multicolumn{2}{|c|}{$0.68 \pm 0.57$}} \\
\hline 422 & $2.00 \pm 0.71$ & $\mathrm{~S}$ & 636 & $2.50 \pm 1.29$ & $\mathrm{~S}$ & $1210(5)$ & $1.20 \pm 1.30$ & $\mathrm{~S}$ & & & \\
\hline
\end{tabular}

${ }^{\mathrm{a}} \mathrm{GI}$ (gall index) was assigned as $0=0-10 \%, 1=11-20 \%, 2=21-50 \%, 3=51-80 \%, 4=81-90 \%$, and $5=91-100 \%$ of roots galled (Baker, 1985 ) ${ }^{b}$ Host reaction of carrot lines determined by $\mathrm{GI} \leq 0.1$, highly resistant (HR); GI $\leq 1$, resistant (R); GI $>1$, susceptible (S) (modified from Sasser et al., 1984). ${ }^{c}$ Means \pm standard deviations of five replications.

${ }^{\mathrm{d}}$ Average of coefficients of variation (CV) calculated by standard deviations/means of gall indices for the total carrot lines examined. 

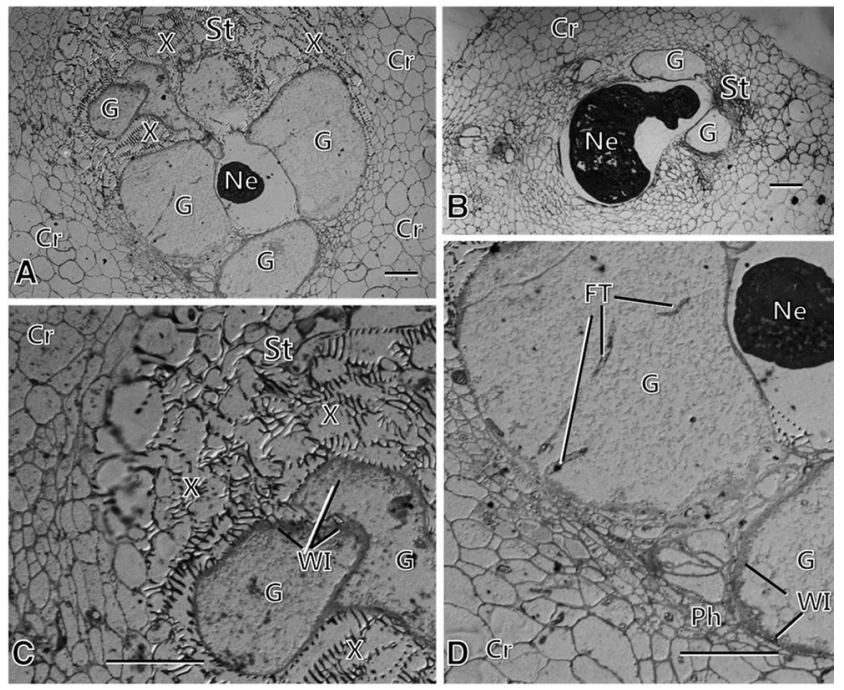

Fig. 2. Light micrographs of susceptible responses in the susceptible carrot line infected with the root-knot nematode at 7 weeks after inoculation, showing well-developed giant cells $(G)$ surrounding the infecting nematodes $(\mathrm{Ne})(\mathrm{A}, \mathrm{B}, \mathrm{D})$, characterized by enormously enlarged cells formed in the stele (St), and feeding tubes (Ft) and cell wall ingrowths (WI) formed in the cytoplasm and adjacent to xylem vessels $(\mathrm{X})$ and phloem $(\mathrm{Ph})(\mathrm{C}, \mathrm{D})$. Note intact-looking nematodes $(\mathrm{B}, \mathrm{D})$. Cr: cortex. Bars $=50 \mu \mathrm{m}$.

analysis/ coefficient_of_variation.html; Reed et al., 2002)). The slight variation in GI may suggest that genotypes for nematode resistance may not be totally homogeneous, which may be derived from the short period of time they were cultivated under pressure of the root-knot nematode infection in the host-pathogen system. This provides little opportunity to select for resistant genes that mitigate the adverse influences on plant fitness (reproductive success) by pathogen infection (Leonard, 2006).

Despite the variance in the GI, no plant had a GI over 2.0, showing an evident susceptibility to nematode infection, suggesting that resistant genotypes were conserved in resistant lines. Also, light micrographs of the root tissues infected with the nematode showed clearly different responses to nematode infection between the susceptible $(\mathrm{GI}=5.0)$ and resistant $(\mathrm{GI}=1.0)$ carrots. In the susceptible carrot, prominent giant cells formed around the infecting nematodes, looking intact and well grown. Feeding tubes and cell wall ingrowths were readily found in the giant cells, suggesting that nematode feeding and nutritional provision by the giant cells to the nematode still may be active until the later stages of nematode infection, as shown in the same sedentary endoparasitic nematode Heterodera glycines (Kim et al., 1999, 2012). These structural characteristics in the susceptible carrot

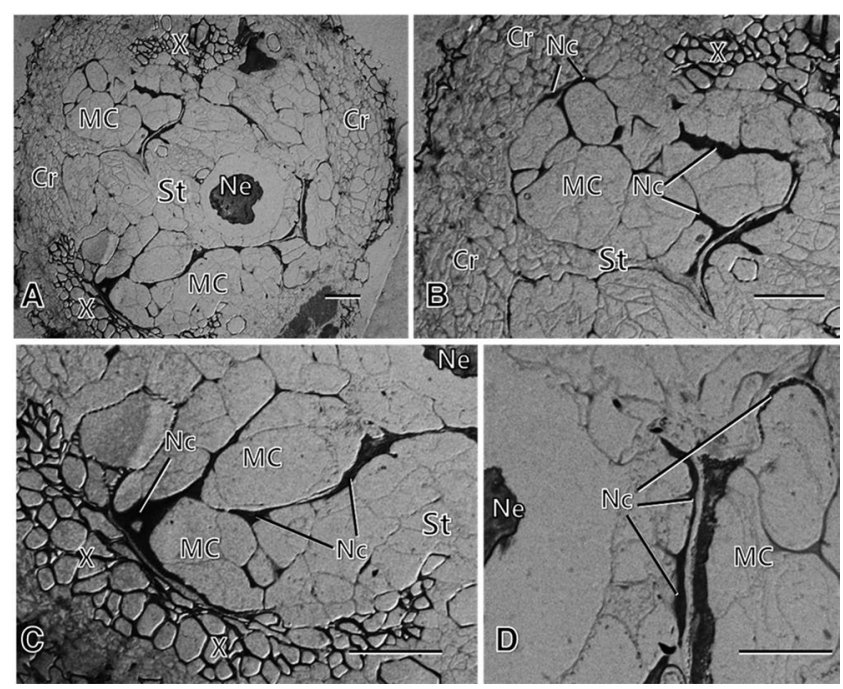

Fig. 3. Light micrographs of root tissues of the resistant carrot line infected with the root-knot nematode at 7 weeks after inoculation, showing the formation of relatively small modified cells (MCs) around the infecting nematodes (Ne) in the stele (St) (A, C, D), and the formation of extensive necrotic layers $(\mathrm{Nc})$ through the middle lamella of the modified cells and around the nematodes, demarcating the modified cells from each other and from the infecting nematodes $(\mathrm{B}, \mathrm{C}, \mathrm{D})$. Note degenerativelooking nematodes (A, C, D). Cr: cortex. Bars $=50 \mu \mathrm{m}$.

are related to the typical susceptible responses in cultivars and lines susceptible to the root-knot nematode (Moon et al., 2010) as galls and giant cells may provide the parasites with the energy required to invade plant roots (Shepherd and Huck, 1989). On the other hand, only modified cells formed in the resistant carrot root tissues infected with the root-knot nematode, with an extensive formation of necrotic layers around the small and degenerative-looking nematodes, which may have resulted from hypersensitive responses (HR) that have been suggested as resistant histopathological features in the root-knot nematode and soybean cyst nematode (Agrios, 2005; Kim et al., 2010, 2012; Moon et al., 2010; Paulson and Webster, 1972). The inhibition of giant cell formation and development may be related to the inhibition of nematode growth and development (Jones, 1981). The formation of necrotic layers around the modified cells may be an incompatible response to the nematode infection and reflect the expression of resistant genes against the infecting nematode (Canto-Sáenz, 1985; Kim et al., 1987). Therefore, these results suggest that the resistance of carrots to the root-knot nematode may not be derived from disease escape (sometimes misleading to resistant responses; apparent resistance) but from the expression of true resistance genes to enable the development of resistant 
carrot cultivars through breeding programs.

A detailed examination of gall formation in the carrot lines revealed a difference in disease severity showing minimum (0.0) and maximum (5.0) GI values in resistant and susceptible carrots, respectively, suggestive of strong differential responses with a complete suppression of disease development in the resistant carrot. This is a characteristic feature of vertical resistance governed by one or a few major genes whose resistant mechanism is mostly a hypersensitive reaction (followed by necrosis formation) that are used for breeding (Agrios, 2005). A major resistant gene $M i$ was identified in a wild Lycopersicon species (L. peruvianum) and introduced to L. esculentum by backcrossing (Ellis, 1943; Watts, 1947). Another resistant gene found in $L$. peruvianum isolates of $\mathrm{Mi}$ gene-compatible Meloidogyne populations governs a type of vertical resistance because of race-specific differential reactions to the nematode infection (Roberts et al., 1990). This information strongly suggests that the resistant reaction of the resistant carrot lines against M. incognita may be derived from vertical resistance governed by the expression of one or a few major genes. Therefore, the Korean carrot lines with resistant responses against the root-knot nematode infection and little variation in GI may be potential genetic resources that can be used to develop carrot cultivars (or hybrids) resistant to the rootknot nematode.

\section{Aknowledgement}

This study was conducted with a financial support from the Ministry of Agriculture, Food and Rural Affairs, Republic of Korea.

\section{References}

Agrios, G. N. 2005. Plant pathology, 5th ed. Academic Press, San Diego, CA. USA. 922 pp.

Anwar, S. A and McKenry, M. V. 2010. Incidence and reproduction of Meloidogyne incognita on vegetable crop genotypes. Pakistan J. Zool. 42:135-141.

Baker, K. R. 1985. Nematode extractions and bioassays. In: An advanced treatise on Meloidogyne. Vol. II. Methodology, eds. by K.R. Baker, C.C. Carter, and J.N. Sasser, pp. 19-35. North Carolina State University, NC, USA.

Bridge, J. and Starr, J. L. 2007. Plant nematodes of agricultural importance: A color handbook. Academic Press, San Diego, CA, USA.

Canto-Sáenz, M. 1985. The nature of resistance to Meloidogyne incognita (Kofoid \& White, 1919) chitwood, 1949. In: An advanced treatise on Meloidogyne, Vol. 1. Biology and Control, eds. by J. N. Sasser and C. C. Carter, pp. 225-231.
North Carolina State University Graphics, Raleigh, NC, USA.

Chakraborty, S., Tiedemann, A. V. and Teng, P. S. 2000. Climate change: Potential impact on plant disease. Environ. Pollut. 108:317-326.

Choi, C. J., Lee, C. H., Lee, S. S., Choi, K. S. and Ryu, J. S. 1974. Studies on the characteristics with cultivating season and correlation between some phenotype of carrot, Dacus carota L. varieties. Res. Rept. REA (Hort.) 16:37-45 (in Korean).

Ellis, D. E. 1943. Root-knot resistance in Lycopersicon peruvianum. Plant Dis. Rep. 27:402-404.

Harris, J. A., Hobbs, R. J., Higgs, E. and Aronson, J. 2006. Ecological restoration and global climate change. Restor. Ecol. 14:170-176.

IPCC (Intergovernmental Panel on Climate Change). 2007. Climate change. In: Synthesis report. Contribution of working group I, II, and III to the fourth assessment of the Intergovernmental Panel on Climate Change, eds. by R.K. Pachauri and A. Reisinger. IPCC, Geneva, Switzerland.

Johnson, A. W. and Fassuliotis, G. 1984. Nematode parasites of vegetable crops. In: Plant and insect nematodes, ed. by W. R. Nickle, pp. 323-327. Marcel Dekker, Inc., New York, N. Y., USA.

Jones, M. G. K. 1981. Host cell responses to endoparasitic attack: Structure and function of giant cells and syncytia. Ann. Appl. Biol. 7:353-372.

Kim, D. G. 2001. Occurrence of root-knot nematodes on fruit vegetables under greenhouse conditions in Korea. Res. Plant Dis. 7:69-79 (in Korean).

Kim, D. G. and Choi, S. K. 2001. Effects of incorporation method of nematicides on reproduction of Meloidogyne arenaria. Kor. J. Appl. Entomol. 40:89-95 (in Korean).

Kim, D. G., Choi, D. R. and Lee, S. B. 2001a. Effects of control methods on yields of Oriental melon in fields infested with Meloidogyne arenaria. Res. Plant. Dis. 7:42-48 (in Korean).

Kim, D. G., Lee, Y. G. and Park, B. Y. 2001b. Root-knot nematode species distributing in greenhouses and their simple identification. Res. Plant Dis. 7:49-55 (in Korean).

Kim, Y. H., Riggs, R. D. and Kim, K. S. 1987. Structural changes associated with resistance of soybean to Heterodera glycines. J. Nematol. 19:177-187.

Kim, Y. H., Riggs, R. D. and K. S. Kim. 1999. Heterodera glycines-induced syncytium structures related to the nematode growth and reproduction in susceptible soybean cultivars. Plant Pathol. J. 15:1-7.

Kim, Y. H., Kim, K. S. and Riggs, R. D. 2010. Differential subcellular responses in resistance soybeans infected with soybean cyst nematode races. Plant Pathol. J. 26:154-158.

Kim, Y.H ., Kim, K. S. and Riggs, R. D. 2012. Initial subcellular responses of susceptible and resistant soybeans infected with the soybean cyst nematode. Plant Pathol. J. 28:401-408.

Kinloch, R. A. and Hinson, K. 1972. The Florida program for evaluating soybean (Glycine max (L.) Merr.) genotypes for susceptibility to root-knot nematode disease. Proc. Soil Crop 
Sci. Florida 32:173-176.

Korean Society of Plant Pathology. 2009. List of plant diseases in Korea, 5th ed. Korean Society of Plant Pathology, Suwon, Korea.

Leonard, K. J. 2006. Selection pressures and plant pathogens. Ann. New York Acad. Sci. 287:207-222.

Ministry for Food, Agriculture, Forestry and Fisheries, Republic of Korea. 2012. Food, agriculture, forestry and fisheries statistic yearbook 2012. Ministry for Food, Agriculture, Forestry and Fisheries, Republic of Korea.

Moon, H. S., Khan, Z., Kim, S. G., Son, S. H. and Kim, Y. H. 2010. Biological and structural mechanisms of disease development and resistance in chili pepper infected with the root-knot nematode. Plant Pathol. J. 26:149-153.

Park, Y. 1995a. Breeding of brown anther type male sterile lines with high phenotypic stability in carrots. J. Kor. Soc. Hort. Sci. 36:1-9 (in Korean).

Park, Y. 1995b. Selection of petaloid type male sterile lines with white petal color in carrots. J. Kor. Soc. Hort. Sci. 36:10-20 (in Korean).

Park, Y. and Pyo, H. K. 1977. Inheritance of male sterility in the carrot (Dacus carota L.). J. Kor. Soc. Hort. Sci. 18:48-59 (in Korean).

Park, Y. and Pyo, H. K. 1988a. Genetical study of male sterility in carrots, Dacus carota L. I. Inheritance of male sterility. $J$. Kor. Soc. Hort. Sci. 29:178-190 (in Korean).

Park, Y. and Pyo, H. K. 1988b. Genetical study of male sterility in carrots, Dacus carota L. II. Breeding of maintenance lines. J. Kor. Soc. Hort. Sci. 29:266-271 (in Korean).

Park, Y. and Pyo, H. K. 1989. Genetical study of male sterility in carrots, Dacus carota L. III. Inheritance and phenotypic stability of male sterility in 'Shin Korota I' and 'Spartan Bonus.' J. Kor. Soc. Hort. Sci. 30:7-10 (in Korean).

Park, Y., Cho, M. S. Kim, Y. S. and Park, S. G. 2002. A promising carrot mutant, spineless seeds. J. Kor. Soc. Hort. Sci. 43:707709 (in Korean).

Paulson, R. E. and Webster, J. M. 1972. Ultrastructure of the hypersensitive reaction in roots of tomato, Lycopersicon esculentum L., to infection by the root-knot nematode, Meloidogyne incognita. Physiol. Plant Pathol. 2:227-234.

Pyo, J. S., Lee, S. W. and Kim, Z. H. 2001. Path coefficient analysis of major characters on root weight of Dacus carota $\mathrm{L}$. J. Agric. Life Sci. 35:31-38 (in Korean).

Pyo, J. S., Lee, S. W. and Kim, Z. H. 2002. Path analysis of major characters affecting selection score in breeding of Dacus carota L. J. Agric. Life Sci. 36:27-37 (in Korean).

Reed, G. F., Lynn, F. and Meade, B. D. 2002. Use of coefficient of variation in assessing variability of quantitative assays. Clin. Diagnost. Lab. Immunol. 9:1235-1239.

Rhoades, H. L. 1976. Effects of Indigofera hirsuta on Belonolaimus longicaudatus, Meloidogyne incognita, and M. javanica and subsequent crop yield. Plant Dis. Rep. 60:384-386.

Roberts, P. A. 1987. The influence of planting date of carrot on Meloidogyne incognita reproduction and injury to roots. Nematologica 33:325-342.

Roberts, P. A., Dalmasso, A., Cap, G. B. and CastangnoneSereno, P. 1990. Resistance in Lycopersicon peruvianum to isolates of $\mathrm{Mi}$ gene-compatible Meloidogyne populations. $J$. Nematol. 22:585-589.

Sasser, J. N., Carter, C. C. and Hartman, K. M. 1984. Standardization of host suitability studies and reporting of resistance to rootknot nematodes. Crop Nematode Research Control Project, NCSU/USAID. Department of Plant Pathology, NCSU, Raleigh, NC, USA.

Shepherd, R. L. and Huck, M. G. 1989. Progression of rootknot nematode symptoms and infection on resistant and susceptible cottons. J. Nematol. 21:235-241.

Simon, P. W., Freeman, R. E., Vieira, J. V., Boiteux, L. S., Briard, M., Nothnagel, T., Michalik, B. and Kwon, Y. S. 2008. Carrot. In: Handbook of plant breeding, vol. 2. eds. by J. Prohens and F. Nuez, pp. 327-357. Springer, New York, NY, USA.

Siroka, R. A. and Fernandez, E. 1990. Nematode parasites of vegetables. In: Plant parasitic nematodes in subtropical and tropical agriculture, eds. by M. R. Luc, A. Siroka, and J. Bridge, pp. 319-392. (eds.). CAB Bioscience, Egham, UK.

Son, S. H., Khan, Z., Kim, S. G. and Kim, Y. H. 2008. Effects of seed treatment with rhizobacterium, Paenibacillus species on management of root-knot nematode-Fusarium wilt fungus disease complex in tomato plants. Russ. J. Nematol. 16:97105.

Southey, J. F. 1986. Laboratory methods for work with plant and soil nematodes. Ministry of Agriculture Fisheries and Food, HMSO, London, UK.

Spurr, A. R. 1969. A low viscosity epoxy resin embedding medium for electron microscopy. J. Ultrastr. Res. 26:31-43.

Watts, V. M. 1947. The use of Lycopersicon peruvianum as a source of nematode resistance in tomato. Proc. Amer. Soc. Hort. Sci. 49:233-234. 